\title{
The Impacts of El-Niño-Southern Oscillation (ENSO) on Agriculture and Coping Strategies in Rural Communities of Ethiopia: Systematic Review Article
}

\author{
Ginjo Gitima $^{1 *}$ and Mengiste Mersha ${ }^{1}$ \\ ${ }^{1}$ Department of Geography and Environmental Studies, University of Gondar, Gondar, \\ Ethiopia.
}

Authors' contributions

Both authors GG and MM equally contributed to this paper and thus, share equal authorship.

Article Information

DOI: $10.9734 / A J G R / 2020 / v 3 i 430117$ Editor(s):

(1) Dr. Hani Rezgallah Al-Hamed Al-Amoush, Al al-Bayt University, Jordan.
Reviewers:

(1) Breno Barra, Federal University of Santa Catarina, Brazil.

(2) R. D. Mavunda, University of Johannesburg, South Africa.

(3) Irshad Ullah, Pakistan.

Complete Peer review History: http://www.sdiarticle4.com/review-history/55608

Systematic Review Article

Received 15 January 2020

Accepted 21 March 2020

Published 18 November 2020

\begin{abstract}
The principal cause of drought in Ethiopia is asserted to be the fluctuation of the global atmospheric circulation, which is triggered by Sea Surface Temperature Anomaly (SSTA), occurring due to El Niño-Southern Oscillation (ENSO) events. It can make extreme weather events more likely in certain regions in Ethiopia. ENSO episodes and events, and related weather events have an impact on seasonal rainfall distribution and rainfall variability over Ethiopia. Thus, the main aim of this review was to identify and organize the major impacts of El-Niño-Southern Oscillation (ENSO) on agriculture and adaptation strategies of rural communities in Ethiopia. Most of the rural communities in the country depend on rain-fed agriculture, and millions of Ethiopians have lost their source of food, water, and livelihoods due to drought triggered by ENSO. The coping strategies against ENSO induced climate change are creating a collective risk analysis, and Climate-Resilient Green Economy (CRGE) at the national level. In addition, community-based coping strategies for ENSO are integrated with watershed management, livelihood diversification and land rehabilitation to better cope with erratic rainfall and drought risks in the country.
\end{abstract}


Keywords: El-Niño-Southern oscillation; drought; coping strategies; Ethiopia.

\section{INTRODUCTION}

The evidence for climate variability or change is certain, and its impacts are already being felt globally [1]. Climate variability associated with $\mathrm{El}$ Niño-Southern Oscillation (ENSO) is a climatic event which has significant impacts on agricultural production, food security and rural livelihoods in many parts of the world [2]. La Niña and El Niño conditions are opposite phases of what is known as the El Niño-Southern Oscillation (ENSO) cycle [3]. ENSO describes naturally occurring climatic conditions which result from the tropical Pacific Ocean [4] and atmospheric temperature fluctuations that can have major implications on global weather patterns [5]. ENSO influences the global dynamics of seasonal winds, rainfall, temperature, and year-to-year variations in ocean temperatures in the tropical Pacific [6]. Additionally, "teleconnections" from the Indian and Atlantic Oceans are assumed to play active roles in ENSO evolution [7,8,9]. Dipole or the uniform basin-wide warming in the Indian Ocean can affect the ENSO cycle by modifying the zonal winds in the tropical Pacific [10]. The extreme events of ENSO termed as El Niño and La Niña, encompass a wide range of natural climatic conditions [11,12]. ENSO also changes surface temperature, wind and moisture that affect rain-fall intensity, duration, and pattern, which can lead to extreme events such as flooding and drought [13].

El Niño (the Spanish name for a male child) is periodic climate variability and climate change phenomenon defined by anomalously warm sea surface temperatures in the Eastern and Central tropical Pacific Ocean [14], which affects local weather worldwide and generally leads to increased drought risk at the global level [15]. It is the warming of sea surface temperatures in the tropical Pacific, which occurs roughly every two to seven years, lasting from six to twentyfour months [16]. El Niño episode occurs when the large-scale atmospheric pressure differs between the Eastern and Western side of the Pacific, and is characterized by warmer than normal temperature and covering the wide Central and Eastern tropical Pacific [17]. In turn, La Niña (female child), the cool phase which typically occurs the year after an El Niño event, often brings extensive damage from floods and heavy rainfall [5] and it occurs when the Sea
Surface Temperatures (SSTs) substantially colder than normal [6].

In Sub-Saharan Africa (SSA), farm households are particularly exposed to weather-induced risks due to the preponderance of rain-fed agricultural production and imperfect market conditions. Climate variability with El Niño-Southern Oscillation (ENSO) exacerbates these risks by increasing the probability and severity of adverse weather conditions [18].

The El Niño-Southern Oscillation (ENSO) is the main driver of the inter-annual variability in Eastern African rainfall, with a significant impact on agriculture and dire consequences for food and social security [19]. In Eastern Africa, the EI Niño phenomenon is generally associated with wetter-than-normal seasonal rainfall variability in the second part of the year though the specific impact depends on the intensity and duration of the El Niño episode coupled with the response of the Indian Ocean conditions. The effects of this weather phenomenon are most concerning for the Horn of Africa in particular, where continued below-average rainfall is across the main growing and sowing months, with a very significant potential impact on food insecurity and malnutrition [15]. In addition, the impact of El Niño climate variability on crop production would be mainly through a change in temperature, rainfall, which collectively influence the length of the growing period, time of critical growth rate, increased evapotranspiration and hence seriously reduced and in some cases causes complete crop failure [20].

The principal cause of drought in Ethiopia is asserted to be the fluctuation of the global atmospheric circulation, which is triggered by Sea Surface Temperature Anomaly (SSTA), occurring due to ENSO events. The phenomena have a significant impact on the displacement and weakening of the rain-fed agricultural production in the seasons [21]. Ethiopia is also one of the most affected by the El Niño phenomenon because most of the rural communities depend on seasonal rainfall, and millions of Ethiopians have lost their source of food, water, and livelihoods. The country's Afar, Somali and Oromia regions have been particularly hard hit. Water sources have dried up, pastoralists no longer find pasture for their animals and between $50 \%$ and $90 \%$ of crops 
have failed. The loss of animals, a source of milk and protein, is having a negative effect on the nutritional status of children [22,23,24]. Therefore, this paper is aimed to review the impacts of El-Niño-Southern Oscillation (ENSO) on agriculture and its adaptation strategies of rural communities in Ethiopia.

\section{LITERATURE REVIEW}

\subsection{Historical El Niño-Southern Oscillation (ENSO) Episodes and Intensities in Ethiopia}

Climate trends especially rainfall patterns are highly complex due to the varied topography of the country and the seasonality, duration, intensity and irregularity of rainfall. Annual rainfall patterns in Ethiopia (and more generally in the Greater Horn of Africa) are linked with regional Sea Surface Temperatures (SSTs) in the Indian Ocean: warmer Indian Ocean SSTs are linked to dryness [25]. Climatic variability in the strength of warming of the Indian Ocean strongly influences precipitation totals in Ethiopia and accounts for important climatic phenomena such as the decline in rainfall between the 1960s and 1980s (especially in most parts of Ethiopia) and the devastating drought of 1984. Thus, El Niño Southern Oscillation (ENSO) cycles affect the rainfall patterns in Ethiopia [26,27].

Several studies made on drought incidents revealed that extreme climatic events have been increasing in recent decades in the country. According to Comenetz, et al. [28], the El Niño of $1957 / 58$, the coincidence of warm ENSO episodes and droughts in Ethiopia in 1965, 1972/73, 1982/83, 1986, 1991/93, and 1997/98 became quite evident. During 1997/98 El Niño, highly anomalous rainfall distributions were experienced in Ethiopia. As a result, during the Kiremt season which is agriculturally very important, the rainfall distributions were erratic and deficient. On the contrary, untimely and heavy rains with floods were observed during October through January which was supposed to be the dry season in Ethiopia. These abnormalities associated with the 1997/98 El Niño resulted in the reduction of crop production, the outbreak of cholera and cerebral malaria, the loss of life and property [29].

In the 1980s, the anomalies of Sea Surface Temperature in the South Atlantic and Indian Oceans, exacerbated by anthropogenic activities, impacted the rainfall supply in the country [30].
Haile [30] describes that the Ethiopian drought is caused by ENSO and the occurrence of drought in whole Ethiopia is associated with deviations from rainfall every eight to ten years. Attia and Abulhoda [31] also reported that "ENSO episodes are negatively connected with the floods of the Blue Nile and Atbara" rivers that originate from Ethiopia. Eltahir [32] also concluded that ENSO events affect flows of the Nile River (indicating drought in the highland of Ethiopia, which is a source of 85 percent of Nile water) and that knowledge of these events could be used to improve the predictability of its annual flow. Indeed, this indicates an association between ENSO events and droughts in Ethiopia.

Furthermore, Mersha and Van [33] reported that the major droughts had occurred in the last four decades in Ethiopia: 1984/85, 1987/88, 1991, 1994, 1997/98, 2002/03, 2010/11 and 2015/16. In 1984 drought-hit an extensive area ranging from Northern and Central to Eastern Ethiopia, thus impacting a large number of people [33]. The 2015/16 drought covered similar areas and showed an even larger precipitation decline than the 1984 drought [34]. The FAO Agricultural Stress Index System (ASIS) has also assessed the crop growing conditions in El Niño episodes from 1986 to 2013 and in particular, detected agricultural areas with a high likelihood of water stress or drought in Ethiopia. During the period for which ASIS data is available, a total of nine EI Niño events occurred, with varying levels of intensity. In Ethiopia, four out of the nine El Niño years -1987, 1991, 2002 and 2009 - coincided with intense and/or extended drought conditions from April to November, which encompassed the main cropping season. However, the relationship between El Niño intensity and impacts is not clearly linear or straightforward in the country [14].

According to Koo, et al. [35], ENSO events in Ethiopia were grouped into three periods: 2015/16 El Niño, 2016/17 La Niña, and neutral years (that is, 2012/13, 2013/14, 2014/15, and 2017/18). The simulated yield consequences of climate variability associated with the ENSO phases on each grid cell were aggregated at the agro-ecological zone level. Only the Meher season was considered because it accounts for around 96 percent of Ethiopia's total annual production and was the worst-affected season during the 2015/16 ENSO events: El Niño and La Niña-combined to determine the final agricultural yields in Ethiopia. For instance, for the most part 
of the country where precipitation changeability is regularly happening during sowing and crop mounting episodes, seasonal precipitation calculation is extensive for rain-fed agricultural areas, but the intensity of El Niño is not linear [35].

\subsubsection{Rainfall, drought and EI Niño in Ethiopia}

Rainfall in Ethiopia is influenced by the weather systems that evolve in the Pacific Ocean, especially the Central and Eastern-Central parts of the Pacific around the equator $[17,28]$. One of the main factors driving these systems is the temperature of the Pacific's surface because this affects the air pressure above the sea, and related wind and rainfall patterns across large areas of the tropics and sub-tropics [36]. Relatively large changes in the sea's temperature create unusual weather patterns, such as drought or excessive rainfall and storms.

The relationship between El Niño events and drought in Ethiopia has been known for many years $[17,28]$. A detailed list of El Niño and La Niña events and crises in Ethiopia is shown in Table 1. While forecasting the intensity of an El Niño episode is difficult, in Ethiopia there was general agreement that an El Niño episode has a high probability to cause $[14,29,42,57,17]$ : Above-normal rainfall from October to March in the South and Southeastern areas; typically, associated with supporting pastoralist areas due to good pasture but can also cause flooding and outbreaks of human and livestock diseases, above-normal belg rains with an early onset as early as January or February. At the sometime, harvesting the main season cereal crops between October and November may be disrupted due to off-season rains, and belownormal kiremt rains that are also typically late, erratic and shorter than usual.

\subsection{Indicators of the ENSO Signal in Ethiopia}

Some literatures identified ENSO signal in 2015 to be one of the highest Sea Surface Temperature $\left(2.2^{\circ} \mathrm{C}\right.$ for the $2015 / 2016$ [21]; the strongest event around the Niño-3.4 [43,6]; was recorded in the Pacific Ocean during which Ethiopia experienced one of the worst drought episodes over decades. There were also no negative SSTs monthly anomalies during the 2014/2015-2016 SSTs. Then, anomaly increased from January 2014 to August 2014, remained positive between +1.5 and $+2.5^{\circ} \mathrm{C}$ from September 2014 to May 2015, followed by a slight decrease during June 2015. The pattern changed in July 2015, reaching record level $+3.0^{\circ} \mathrm{C}$ in October. In August 2015, anomalies also increased to positive but were followed by a strong negative value during September 2015 [44].

As a result, in June 2015, the government of Ethiopia declared the failure of the spring rains causing the national harvest, which accounts for $10 \%$ of the country's production, to fall well below average in June/July. This affected smallholder farmers and pastoralists in the Northeastern rangelands of Afar and the Northern Somali regions as well as Eastern cropping areas of Northeastern Amhara, Eastern Tigray, Central \& Eastern Oromia and the lowlands along the Rift Valley in Southern Nations, Nationalities, and Peoples' Region (SNNPR) [45]. Due to El Niño induced poor summer rainfall in 2015, the main seasonal assessment report indicated a 50\% reduction of crop production in most of kiremt rain-dependent areas of the country and the number of the population requiring emergency relief food assistance increased to 10.2 million in January 2016 [40].

\subsection{Seasonal Forecast Problems of EI Niño- Southern Oscillation (ENSO)}

ENSO is a regional oceanic and atmospheric phenomenon with global consequences. Its study and dissemination have both global and regional importance. ENSO's forecast effectiveness and limitations should be seen based on its relevance to the various hierarchies of users. The information is important for regional policymakers to plan agricultural trade within and between countries and for relief transfers at a global level. The key issue is how to use ENSO at the village level, where the subsistence farmers need specific local information [46]. However, seasonal forecast problems of ENSO happened in the global natural climate system that involves a cyclic shift in both the ocean and the atmosphere in the tropical Pacific. In the seasonal forecast issued for February to May, the rainfall duration and intensity during this season are not related to El Niño or La Niña conditions and forecasts have been disreputably not reliable for forecasting rainfall deficits of climatic events in the past [46]. 
Table 1. History of EI Niño- Southern Oscillation (ENSO) events and Drought/Famine in Ethiopia

\begin{tabular}{|c|c|c|}
\hline El Niño years & Events occurred & Affected areas \\
\hline $1957-58$ & $\begin{array}{l}\text { Droughts and flooding in } 1957 \text {, combined with locust } \\
\text { as well as the } 1958 \text { outbreak of epidemic }\end{array}$ & $\begin{array}{l}\text { The impact on human and animal mortality in Tigray and Amhara (North Wollo } \\
\text { areas) was high) }[38,39] \text {. }\end{array}$ \\
\hline $1965-66$ & Rain failure and famine. & Affected the Tigray and Amhara (Wollo areas) $[38,39]$. \\
\hline 1972-1974 & $\begin{array}{l}\text { Droughts and successive failure of Meher rains- } \\
\text { induced food shortages. Killed } 50 \% \text { of livestock. }\end{array}$ & $\begin{array}{l}\text { Ethiopia, particularly the Tigray, Amhara (Wollo) as well as Afar (Ogaden } \\
\text { areas) }[38,39] \text {. }\end{array}$ \\
\hline 1979 & The Belg rains failure. & Affected Southern Ethiopia. \\
\hline 1982-1984 & $\begin{array}{l}\text { Drought and late come seasonal rains. Droughts and } \\
\text { famine causing hundreds of thousands death and } \\
\text { migration in search of employments in the state farms } \\
\text { in Eastern and coffee producing areas of the Southern } \\
\text { region. }\end{array}$ & $\begin{array}{l}\text { Whole Ethiopia, most farmers were in need of emergency food assistance } \\
{[38,39] \text {. }}\end{array}$ \\
\hline $1986-87$ & Droughts and food shortages & $\begin{array}{l}\text { Whole Ethiopia, particularly in Tigray and Northern Wollo, North Shoa, } \\
\text { NorthEastern Gondar, and Hararege highlands }[38,39] \text {. }\end{array}$ \\
\hline $1991-92$ & Continues rain failures and military conflicts & Whole Ethiopia, particularly Northern, Eastern, and Southern Ethiopia $[38,39]$. \\
\hline 1993-94 & $\begin{array}{l}\text { Droughts strike that caused an estimated } 4 \text { million } \\
\text { people demanded food aid. }\end{array}$ & $\begin{array}{l}\text { Higher magnitude was recorded in the Tigray and Wollo areas of the North as } \\
\text { well as Addis Ababa }[38,39] \text {. }\end{array}$ \\
\hline 1997-1999 & $\begin{array}{l}\text { Prolonged drought and successive rains failure, conflict } \\
\text { and declining livestock prices. The affected population } \\
\text { rose from } 2.7 \text { million in } 1996 \text { to } 7.7 \text { million in } 2000 \\
\text { drought years. Others estimated the figure over } 10 \\
\text { million people in } 2000 \text {. }\end{array}$ & $\begin{array}{l}\text { Particularly affected the Eastern highlands and pastoral lowlands including } \\
\text { Gode, Shinile, Jigjiga, Kebre-dahan of Somali region; Konso, North and South } \\
\text { Omo zone of Southern region; Borena zone of Oromia region; lay-Gayint, } \\
\text { Humera and Wollo areas of Amhara region. Moreover, conflict leads localized } \\
\text { food shortages in Eritrea and Tigray [37]. }\end{array}$ \\
\hline $2002 / 2003$ & $\begin{array}{l}\text { Severe food shortages caused by droughts had an } \\
\text { estimated } 12.6 \text { million people affected. }\end{array}$ & $\begin{array}{l}\text { Affected most part of Ethiopia, particularly Tigray, Oromia, Amhara, Somali and } \\
\text { Afar; even known cereals producing areas including Arsi and Bale highlands of } \\
\text { Oromia region [37]. }\end{array}$ \\
\hline $2008-2009$ & $\begin{array}{l}\text { Localized drought and world food price increase } \\
\text { affected } 6.4 \text { million people. }\end{array}$ & $\begin{array}{l}\text { Affected most part of Ethiopia, particularly Oromia, Somali, Amhara, Afar and } \\
\text { SNNPR.SNNP region particularly the lowland moisture deficit districts [37]. }\end{array}$ \\
\hline 2015-2017 & $\begin{array}{l}\text { Worst droughts in } 30 \text { years affected more than } 10.2 \\
\text { million people who required food assistance in } 2016 \text {. } \\
\text { The continued effects of drought left a large number of }\end{array}$ & $\begin{array}{l}\text { Northern, Eastern Hararege and Central Ethiopia particularly in Afar, in Shinile } \\
\text { zone of Somali region, and parts of Amhara, Oromia, and Southern regions. } \\
\text { Floods recorded in Mustahil, Kelafo, and Eastern Imy in the Shabelle zone of }\end{array}$ \\
\hline
\end{tabular}




\begin{tabular}{|c|c|c|}
\hline El Niño years & Events occurred & Affected areas \\
\hline & $\begin{array}{l}\text { people, in different parts of the country, seeking food } \\
\text { assistance in } 2017 \text {. In addition to the effects of frost, } \\
\text { heavy rainfall and floods were also affected people and } \\
\text { public services. The newly emerged crop diseases } \\
\text { (locally named Temche) spread out rapidly and } \\
\text { affected young maize plants by feeding the leaves. } \\
\text { Traditional controlling mechanisms were often adopted } \\
\text { by the farmers for managing the disease. }\end{array}$ & $\begin{array}{l}\text { Somali region and in Western Arsi zone of Oromia region and in Kindodidaye } \\
\text { area of Wolayita zone of SNNPR. Frost affected the Meher harvest in some } \\
\text { cereals producing areas of Oromia region. Moreover, in } 2017 \text { crop disease } \\
\text { affected maize plants which have been covered on 146,000 hectares of land in } \\
\text { some districts of the Tigray, Oromia and Benishangul-Gumuz and SNNPR } \\
\text { regions [40,41]. }\end{array}$ \\
\hline
\end{tabular}


Most global forecasting centers have declared that El Niño conditions officially began in March 2015 (US-based NOAA and IRI) and in May 2015 (Australian Bureau of Meteorology), these forecasting centers indicated that the thresholds, data sets and parts of the ocean used to observe Sea-Surface Temperatures (SST) differ slightly amongst global forecasting centers', accounting for the differences in the declaration. In mid-May that year, many of the seasonal forecasts produced by global or regional forecasting centers showed some indication of unusually dry conditions for the Kiremt rains in Ethiopia. However, the area, confidence, and timing differed depending on the forecast in the country [34].

Ethiopia is primarily related to the Inter-Tropical Convergence Zone (ITCZ). This indicates ITCZ is highly susceptible to the Southern Oscillation of El Niño (ENSO) [36]. For instance, The International Research Institute for Climate and Society's June-August forecast (issued in May 2015) showed no new information for Ethiopia $[47,48]$. However, the forecasts issued in May [49] and June 2015 [48] indicated that JulySeptember in Eastern Ethiopia would have a $35 \%$ to $55 \%$ increased chance of below-normal rainfall. Finally, the ECMWF long-range forecast for June to August strongly indicated a belownormal season in roughly the correct North, Central and Eastern areas of Ethiopia [34].

However, most forecasters reported in Ethiopia that May and June 2015 showed some form of below-average precipitation for parts of the Horn of Africa, they were not the highly confident indications of the risk of reduced rainfall for the season that decision-makers may have been looking for in order to take action [34]. Therefore, El Niño- Southern Oscillation (ENSO) is a continuous natural climatic event, and making decisions in uncertain conditions is difficult, but there are systems that could be enacted in the future to allow decision-makers to make risk informed decisions far in advance of a disaster and prompt appropriate early action [50]. Hence, an ENSO-based early warning system, used effectively by policymakers, could help to reduce the societal impacts, climate variability, and uncertainty of drought in Ethiopia.

\subsection{The Impacts of El Niño-Southern Oscillation (ENSO) in Various Parts of Ethiopia}

El Niño-Southern Oscillation (ENSO) can make extreme weather events more likely in certain regions in Ethiopia. ENSO episodes and events, and related weather events have an impact on seasonal rainfall distribution and rainfall variability over Ethiopia. Predicting the life cycle and strength of El Niño and La Niña is critical for helping people plan for, avoid, or mitigate potential damages in every sector of society to predict extreme events on rural agricultural production and coping mechanisms of El Niño events in the country. In 2015, in two consecutive poor rainy seasons-belg (February to May) and kiremt (June to September), harvests were well below average with some areas experiencing between 50 and 90 percent crop loss. Many families dependent on agriculture have become indebted and dependent on humanitarian assistance. With inadequate sources of food and income as a result of the drought, vulnerable rural households face widespread hunger and malnutrition [16].

Koo et al. [35] also reported in their study that the effects of the 2015 El Niño-driven drought continued through the remainder of 2016 and into 2017 and beyond for this drought is followed by others in the near future. Similarly, climate variability and extremity such as ENSO events, as well as long-term climate change, will likely put pressure on future agricultural productions in the country [34]. On the other hand, the agriculture-dependent population is expected to grow by about 60 percent between 2010 and 2030. A major shortcoming in the evidence base or literature on EI Niño-Southern Oscillation (ENSO) and other climate shocks in Ethiopia is a lack of differentiation between lowland (largely dry land areas) and highland (more productive areas) conditions with regional variability [49]. Furthermore, climate models suggest that Ethiopia will see further warming of between $0.7^{\circ} \mathrm{C}$ and $2.3^{\circ} \mathrm{C}$ by the $2020 \mathrm{~s}$ and between $1.4^{\circ} \mathrm{C}$ and $2.9^{\circ} \mathrm{C}$ by the 2050s [51]. Generally, the impacts of the 2015/16 El Niño- Southern Oscillation (ENSO) induced episode on agricultural production and its adaptation strategies of rural communities in Ethiopia is organized and reviewed as follows:

\subsubsection{The impacts of El-Niño-Southern Oscillation (ENSO) on agriculture in Northern Ethiopia}

Northern Ethiopia is the area most affected by climate variability and a series of droughts and famine in the country. More than a dozen localized and regional droughts induced by ElNiño episode happened in this area within the 
last four decades and affected agricultural productions negatively and millions of rural poor farmers and their environment $[52,53]$.

In 2015, the ongoing drought in Northern Ethiopia could be associated with El Niño, although a clear causal relationship cannot be fully confirmed. In Northern Ethiopia, an expected low main (Meher) harvest in January 2016 was followed by a drier than normal short season in early 2015 . Also, any abnormal rainfall in the harvesting time in December/January due to El Niño would further deteriorate crop production. In this part of the country, due to the high levels of vulnerability, the risk of increasing food insecurity from 2015 to the next crop season in April 2016 was particularly high [15].

For instance, Belg-dependent smallholder farmers in Lagambo and Dese Zuria districts of South Wollo zone reported that they only planted a quarter of their fields in 2015 as a result of the poor spring (belg) rains and inadequate soil moisture. In the areas that were planted, poor germination and crop establishment were reported, and little or no harvest was expected in June and July. Therefore, most of these fields were grazed by livestock. Belg producing district received some rain in May 2015 and some farmers took the opportunity to plant barley and fodder oats. Almost all belg-dependent smallholder farmers in South Wollo and North Wollo reported the failure of the spring belg harvest [54].

In addition, in the Kombolcha district of South Wollo zone (Northeastern Ethiopia), the total rainfall deficits in 2015 were comparable to those in 1994 and 2002. This illustrated that the drought experienced by Ethiopians on the ground was, in some areas, similar to other events that had occurred in the recent past. For farmers in Kombolcha, as in much of Ethiopia, it was not the total rainfall deficits that resulted in impact, but rather the timing of rainfall. This meant that particular factor was of far greater importance. Farmers usually wait until the first rain to sow their seeds; those in the Kombolcha district who planted early in the season in 2015 did not receive enough rain during the subsequent weeks for their crop to grow. Others waited too long for consistent rainfall and subsequently planted too late, resulting in failed harvests (34). Residents in the area reported that the summer meher rains had been late, erratic and poor with the result that by mid-September 2015 many areas of North and South Gondar were experiencing drought-like conditions. They also reported that, the drought continued to intensify through April 2016 with the result that they experienced increasing hardship and has impacted on different aspects of the lives and livelihoods [54].

El Niño brought a major drought across most of Tigray, with substantial yield losses caused by a late start of the rainfall season and significant dry spells along with it (34). Likewise, AKLDP [55] reported that the immediate and longer-term cause of rural uncertainty in Tigray regional state (especially in Raya Alamata district in South Tigray Zone and Klite Awlaelo district in Eastern Tigray Zone in May 2016 was late start of rainfall. Because in 2015, the belg rain failed and El Niño induced poor summer kiremt rains and poor Meher harvest and lost livestock production, and steadily rising costs of agriculture inputs especially fertilizer and inappropriate timing of loan repayments in the immediate post-harvest period, when farm-gate prices were the lowest in the year. Typically, those able to buy and store cereals and pulses at the point of harvest benefited from higher prices [55].

\subsubsection{The impacts of El-Niño-Southern Oscillation (ENSO) on agriculture in Southern Ethiopia}

El Niño events were peaked at the end of 2015 which were documented to tail off in the course of 2015/2016 in most parts of the SNNP region. This El Niño event is one of the strongest ever recorded, leading to record-high temperature, rainfall, and weather extremes. So, the high levels of production failure and the consequent food insecurity reflected not just only the increased incidence of rain failure and drought but also the hugely increased unpredictability and erratic nature of the rains causing significant crop failure related to the timing of the rains relative to crop production cycles and significant loss from flooding in SNNP region. In 2016, the belg (early season) rains came very late in most areas, and early planted crops were destroyed by flooding in South and Southwestern Ethiopia. The flooding was followed by a cessation of the rains during May, causing widespread fears of another disastrous production year [56].

For instance, in Wolayta zone of SNNPR, some crops were totally lost, predominantly maize and haricot beans, but there was more production diversification, with farmers growing a wider range of crops. So, even where some crops 
failed totally, farmers got some harvests from crops such as potatoes, teff, and cassava. In Wolayta, a Bureau of Agriculture has also recommended drought-resistant root crop, as part of the diversification strategy. As a result, farmers who grew such root crops had got harvests from these crops in the previous drought years when other crops failed and stunted crop in late 2015 and 2016 [56].

The Shebedino district in Sidama zone of SNNP region experienced a heavy loss of product due to early plantings of maize, which was related to flooding. They also lost over 75 percent of enset (false banana, a staple crop of Southern Ethiopia) and 75 to 100 percent of coffee production. Most farmers planted maize again, and were planting sweet potato, but were very anxious about continuing lack of rain. However, there were local variations in crop loss; one group reported that their maize was relatively good that year, though the enset had been washed away in 2015/2016 [56].

Fiona and Mengistu [56] in their study in Kambata zone of Angacha district documented that, in 2015 the potato production was satisfactory, but in late 2016, farmers lost all of the wheat. Then, they bought fertilizer and planted garlic and beetroot, but lost all of it. They were getting some beans, barley, and salad crops using irrigation. They said it was easy to dig and find water in their area. They had planted enset, potatoes, and wheat in year 2016 and some maize, most of which had been lost in earlier flooding. They had recently planted garlic and potatoes, but were worried about getting enough rain in time.

\subsubsection{The impacts of El-Niño-Southern Oscillation (ENSO) on agriculture in South Eastern Ethiopia}

The drought in Afar and Northern Somali areas (lowland areas) probably started with poor summer rains in July and August 2014, before El Niño started. This was followed by failure of the short rains in March and April 2015, and the failure of the summer rains in July and August 2015. In this sequence of events, only the failed summer rains 2015 can be attributed to El Niño [54].

Much of the Ethiopian highlands and the Eastern of the country were hit by a severe drought in 2015-16, associated with the El Niño event of 2015. The El Niño weather system, exacerbated by climate change, came off the back of 12 to 18 months of erratic or failed rains. It led to crop failures of the 2015 meher harvest of between 50 and 90 percent, particularly in the Eastern part of the country, and has dried up many water sources. Hundreds of thousands of livestock have died and malnutrition is at alarming levels. Pastoralists in Afar and Somali regions were some of the first and hardest hit. Pastoralists who have lost income, livestock and access to food and water were migrating and congregating in sites near villages and towns where they hope to have access to water [23].

ENSO events (El Niño and La Niña) have become regular occurrences for pastoral communities of Ethiopia, leading to rainfall uncertainty that affected pasture/rangeland, thereby influencing livestock populations [56]. In this regard, Hassen et al. [56] studied the effect of reduced rainfall on livestock populations in Eastern Ethiopia and reported the declining cattle and sheep population during 2015/2016 El Niño (diminishing rainfall) in Shinile Zone of Somali Region, whereas goats and camels, which are more drought tolerant, were better adapted to low amounts of rain.

\section{COPING STRATEGIES FOR IMPACTS OF EL-NIÑO-SOUTHERN OSCILLATION (ENSO) IN ETHIOPIA}

\subsection{National Level Strategies}

Various strategies that could help mitigate the adverse effects of climate shocks induced by $\mathrm{El}$ Niño-Southern Oscillation (ENSO) were implemented in Ethiopia for the last many decades. The Ethiopian government has already designed and trying to implement such climate resilience programs as Adaptation to Climate Change, the Productive Safety Net Programme (PSNP) and the Agricultural Growth Program [58]. Specifically, these interventions include: onfarm investments in technology and irrigation infrastructure; investments in roads and grain storage facilities to expand and stabilize food markets; and social transfers to provide households with a cushion against immediate crises and opportunities for longer-term recovery [35].

In Ethiopia, through the National Adaptation Program of Action (NAPA) process, twenty priority project ideas have identified that address the immediate climate change adaptation needs of the country. These projects broadly focus on the areas of human and institutional capacity building, improving natural resource 
management, enhancing irrigation agriculture and water harvesting, strengthening early warning systems and awareness-raising quite relevant areas in improving Dry lands livelihood systems [59].

One best coping mechanism for the ENSO induced climate change is establishing a mechanism for collective risk analysis. In this regard, a report by UN Secretariat General's special envoy on El Niño and climate (2016) emphasizes that consolidated analysis needs to be shared early enough with all relevant stakeholders in order for ENSO risk information and early warning to effectively translate into early action. It explicitly refers to communicating the information to those most directly affected in order to facilitate their early action and preparedness. Effective ENSO early warning requires three components: information on the at-risk population; monitoring of the climate conditions and their effects; and communication of the information.

Lying in the sub-Sahara region, Ethiopia is one of the most vulnerable countries to the impacts of climate change. As a result, it has frequently faced with climate change related problems like drought and flood. Currently, it is a well-known fact that climate change poses serious threat to agricultural production, natural resource base and the livelihood of communities. As a response to the aforementioned climate change threats and in fact actual dangers, the federal government of Ethiopia has signed and ratified all the Rio Conventions, namely the United Nations Framework Convention on Climate Change and its protocol, the Bio-Diversity Convention and the Conventions to Combat Desertification. Accordingly, the government of Ethiopia has put in place policies, strategies and programs that enhance the adaptive capacity and reduce the vulnerability of the country to climate variability and in 2012 the Climate Resilient Green Economy (CRGE) initiative was launched to protect the country from the adverse effects of climate change and to build a green economy that will help realize its ambition of reaching middle income country status before 2025 [60].

\subsection{Community Level Strategies}

The Food Policy report by Koo et al. [35] indicated that the basic climate change coping activities implemented in the agrarian highland communities of Ethiopia are: Watershed management through capturing water runoff, increasing water availability (check dams, water harvesting, and moisture harvesting), and terracing; land rehabilitation and reforestation, including the enclosure of eroded land for protection from animals and humans, use of terracing, planting of grasses and agro-forestry, soil fertility management, and promotion of climate-smart agricultural practices; promotion of vegetable production and crop diversity to promote balanced diets and improve the nutritional status of households; distribution of seeds, such as fast-maturing varieties and improved seeds (for example, improved teff and sorghum seeds); and crop insurance to protect farmers against the loss of their crops due to natural disasters such as drought, floods, frost, and snow.

Another study by WFP [61] reveals that farmers adapt their farming strategies to better cope with erratic rainfall and drought risk in most parts of Ethiopia. In addition, crop diversification stands first among the diversified adaptation strategies practiced by smallholder farmers. Farmers are also used to plant improved varieties of crops adapted to moisture-deficit conditions and have diversified into high-value crops like spices and cosmetic plants. These cash crops are sold for higher prices at markets. Similarly, the pastoralist communities in the arid and semi-arid parts of the country implemented livelihood diversification as an adaptation strategy to climate change. Pastoralists have been engaged in different sources of livelihood, such as selling of charcoal, selling camel milk, selling tooth brushes, and small-scale trade [62].

In the rural agricultural and semi-pastoral communities, farmers are using water pumps to expand irrigated farming. Ethiopia is a country endowed with many small and larger rivers and streams flowing almost throughout the year. Taking advantage of this natural endowment, most rural communities having access to these rivers and streams irrigate their farm land either in gravitational system or using water pumps. using these small-scale irrigation practices, the rural community safeguards their family as well as the urban residents from the impacts of $\mathrm{El}$ Nino-Southern Oscillation (ENSO) induced drought.

Some communities have also migrated from vulnerable areas as crisis mitigation strategy. Mobility from areas of scarce water and fodder to other areas was practiced in most pastoralist 
areas of the country. Mobility has served pastoralists as a successful adaptation method to climatic and environmental hazards, as well as to adapt to the difficult nature of the arid environment. However, the effectiveness of this adaptation strategy is facing increasing pressure due to natural resource-based as well as ethnicbased conflicts [62].

Apart from farming, some agro-pastoral communities also raise small ruminants and chickens to compensate for dwindling livestock population owing to climate risks. There is also a shift in animal husbandry in different parts of the country. Some farmers, for instance, shifted their form of animal husbandry from open grazing system to tethered feeding with collected and conserved crop residues as a response to the diminishing grazing resource due to both climate extremes and man-made environmental degradation.

In response to deforestation (both a cause and consequence of climate change), smallholder farmers with the assistance of environmental organizations, have intensified their efforts to protect the remaining woodlands. Residents are encouraged to: reduce and gradually abandon charcoal making; use energy-saving stoves; increase the productivity of land that is already under crop production rather than expanding to virgin land; and adopt agro-forestry practices such as planting multi-purpose trees [63].

\section{CONCLUSION}

El Niño and La Niña have broad-reaching effects on global weather. They caused major global weather and climate fluctuations. In countries like Kenya and Ethiopia where $80 \%$ of people are smallholder farmers and often live hand-tomouth, the effects of these phenomena are more severe. El Niño has a couple of major effects in Ethiopia among which some are: drought or unseasonable dryness due to depressed rainfall in July to September. These droughts were followed by food shortage and sustaining disarray that resulted in fundamental secession and a massive program of population redeployment; flooding or rain-induced crop damage due to strengthened rainfall from October to December across the Horn of Africa.

Setbacks on crop yields, food security and income caused by climate events, like drought or flood, means economic household recovery may take not days or months, but years. Moreover, government, communities and civil society are not yet equipped or resilient to take on the challenge alone. It thus becomes a global imperative to assist.

However, Ethiopia is implementing all possible coping strategies both at national and community levels. At the national level, twenty priority project ideas were identified through the National Adaptation Program of Action (NAPA) process that can address immediate climate change adaptation needs of the country. Similarly, local communities are putting various mechanisms in to practice to cope with the prevailing climate change. water-shed management in the form of terracing, capturing water runoff, afforestation, reforestation, etc. is at the heart of the local community which have brought encouraging results in minimizing the impacts of El-NiñoSouthern Oscillation (ENSO) in Ethiopia.

\section{COMPETING INTERESTS}

Authors have declared that no competing interests.

\section{REFERENCES}

1. Asfaw A, Simane B, Bantider A, Hassen A. Determinants in the adoption of climate change adaptation strategies: Evidence from rainfed-dependent smallholder farmers in North-central Ethiopia (Woleka Sub-Basin). Environment, Development and Sustainability. 2019;21(5):2535-65.

2. Deng $X$, Huang J, Qiao $F$, Naylor RL, Falcon WP, Burke M, Rozelle S, Battisti D. Impacts of El Nino-Southern Oscillation events on China's rice production. Journal of Geographical Sciences. 2010;20(1):316.

3. Gutierrez L. Impacts of El Niño-Southern Oscillation on the wheat market: A global dynamic analysis. PloS one. 2017;12(6).

4. WMO. El Niño/ Southern Oscillation. 2014; WMO-No. 1145.

5. Sutton WR, Srivastava JP, Rosegrant M, Thurlow J, Vasileiou I. Striking a balance: Managing El Niño and La Niña in Myanmar's Agriculture. World Bank; 2019.

6. Hirons L, Klingaman N. La Niña 2016/2017: Historical impact analysis.

7. Tack JB, Ubilava D. The effect of EI Niño Southern Oscillation on US corn production and downside risk. Climatic Change. 2013;121(4):689-700. 
8. Okumura YM, Sun T, Wu X. Asymmetric modulation of El Niño and La Niña and the linkage to tropical Pacific decadal variability. Journal of Climate. 2017;30(12): 4705-33.

9. Zhang C, Luo JJ, Li S. Impacts of tropical Indian and Atlantic Ocean warming on the occurrence of the 2017/2018 La Niña. Geophysical Research Letters. 2019;46(6): 3435-45.

10. Izumo T, Vialard J, Lengaigne M, de Boyer Montegut C, Behera SK, Luo JJ, Cravatte $\mathrm{S}$, Masson S, Yamagata T. Influence of the state of the Indian Ocean Dipole on the following year's El Niño. Nature Geoscience. 2010;3(3):168-72.

11. Girishkumar MS, Ravichandran M. The influences of ENSO on tropical cyclone activity in the Bay of Bengal during October-December. Journal of Geophysical Research: Oceans. 2012;117(C2).

12. Zhang $Y$, Qian $Y$, Dulière $V$, Salathé EP, Leung LR. ENSO anomalies over the Western United States: Present and future patterns in regional climate simulations. Climatic Change. 2012;110(1-2):31546.

13. Scaife A, Guilyardi E, Cain M, Gilbert A. RMetS Climate Science Communications Group. What is the El Niño-Southern Oscillation? Weather. 2019;74(7):250-1.

14. AKLDP. El Niño in Ethiopia Uncertainties, impacts and decision-making. Agriculture Knowledge, Learning Documentation and Policy (AKLDP) Project, Ethiopia; 2015.

15. Rembold $F$, Leo $O$, Nègre $T$, Hubbard $N$. The 2015-2016 El Niño Event: Expected impact on food security and main response scenarios in Eastern and Southern Africa. Joint Research Centre, the European Commission's, European Union; 2015.

16. FAO. 2015-2016 El Niño: Early Action and Response for Agriculture, Food Security and Nutrition.

17. Ahmed H, Tessema Z, Adugna T, Diriba K. Interconnection between El-Niño-Southern oscillation induced rainfall variability, livestock population dynamics and pastoralists adaptation strategies in Eastern Ethiopia.

18. Arslan A. Climate resilience in rural Zambia: Evaluating farmers' response to El Niño-induced drought; 2018.

19. Fer I, Tietjen B, Jeltsch F, Wolff C. The influence of El Nino-Southern Oscillation regimes on Eastern African vegetation and its future implications under the RCP8. 2017; 5 warming scenario.

20. Mahoo H, Radney M, Kinyanji J, Cramer L, Eds. Climate change variability and risk assessment of agriculture and food security in Ethiopia: Which way forward? CCAFS Working Paper N0. 59. CGIAR Research Program on Climate Change, Agriculture and Food Security (CCAFS). Copenhagen, Denmark; 2013.

21. Alemu A, Korecha D, Mohamod M. Impacts of various ENSO phases on cereal crop productivity in the Upper Awash Basin, Central High Land of Ethiopia. In Proceedings of the International Conference on Impact of El Niño on Biodiversity, Agriculture, and Food Security, 23-24 February 2017, Harayama University, Ethiopia. 2017;3-18.

22. EC. Humanitarian Aid and Civil Protection, ECHO Factsheet - Ethiopia; 2016.

23. Seaward C. El Niño in Ethiopia: Programme observations on the impact of the Ethiopia drought and recommendations for action. Oxfam International; 2016.

24. Negeri MB. The effects of El Nino on agricultural GDP of Ethiopia. American Journal of Water Science and Engineering. 2017;3(4):45-9.

25. Williams AP, Funk C, Michaelsen J, Rauscher SA, Robertson I, Wils TH, Koprowski M, Eshetu Z, Loader NJ. Recent summer precipitation trends in the Greater Horn of Africa and the emerging role of Indian Ocean Sea surface temperature. Climate Dynamics. 2012;39(9-10):2307-28.

26. Lyon B, DeWitt DG. A recent and abrupt decline in the Eastern African long rains. Geophysical Research Letters. 2012;39(2).

27. Krishnamurthy PK, Hobbs C, Matthiasen A, Hollema SR, Choularton RJ, Pahari K, Kawabata M. Climate risk and food security in Nepal-analysis of climate impacts on food security and livelihoods; 2013.

28. Comenetz J, Caviedes C. Climate variability, political crises and historical population displacements in Ethiopia. Global Environmental Change Part B: Environmental Hazards. 2002;4(4):113-27.

29. Babu A. The impact of Pacific sea surface temperature on the Ethiopian rainfall. In Workshop on High-Impact Weather Predictability Information System for Africa and AMMA-THORPEX Forecasters' Handbook, Trieste, Italy. 2009;5-8. 
30. Haile T. Causes and characteristics of drought in Ethiopia. Ethiopian Journal of Agricultural Sciences; 1988.

31. Attia BB, Abulhoda AB. The ENSO phenomenon and its impact on the Nile's hydrology. Climate Fluctuations and Water Management. Butterworth Heinemann. 1992;71-9.

32. Eltahir EA. El Niño and the natural variability in the flow of the Nile River. Water Resources Research. 1996;32(1): 131-7.

33. Mersha AA, van Laerhoven $F$. The interplay between planned and autonomous adaptation in response to climate change: Insights from rural Ethiopia. World Development. 2018;107: 87-97.

34. Singh $R$, Worku $M$, Bogale $S$, Cullis $A$, Adem A, Irwin B, Lim S, Bosi L, Venton CC. Reality of resilience: Perspectives of the 2015-16 drought in Ethiopia. BRACED Resilience Intel. 2016;6:1-28.

35. Koo J, Thurlow J, EIDidi H, Ringler C, De Pinto A. Building resilience to climate shocks in Ethiopia. Washington, DC: IFPRI; 2019.

36. Worku M, Sahile S. Review on the Impact of El Niño-Southern Oscillation (ENSO) climate changes in Ethiopia. Journal Climate Weather Forecasting. 2018;6:218.

37. WFP and E, CSA. EthiopiaComprehensive food security and vulnerability analysis (CFSVA), 2014. Which Way Forward? CCAFS Working Paper No. 59. CGIAR Research Program; 2014.

38. WFP. Climate impacts on food security. World Food Program; 2015.

Available:https://www.wfp.org/climatechange/climate-impacts

39. Abebe G. Household food insecurity in the Sidama Zone of Southern Ethiopia. Factors, coping and adaptation strategies; 2018.

40. FDRE. Ethiopia-The 2016 Humanitarian Requirements' Document. Joint Government and Humanitarian Partners' Document; 2016.

41. Mera GA. Drought and its impacts in Ethiopia. Weather and Climate. 2018;22: 24-35.

42. Paek H, Yu JY, Qian C. Why were the 2015/2016 and 1997/1998 extreme El Niños different? Geophysical Research Letters. 2017;44(4):1848-56.
43. Lim YK, Kovach RM, Pawson S, Vernieres G. The 2015/16 El Niño event in context of the MERRA-2 reanalysis: A comparison of the tropical Pacific with 1982/83 and 1997/98. Journal of climate. 2017;30(13): 4819-42.

44. Robinson CJ. Evolution of the 2014-2015 sea surface temperature warming in the central west coast of Baja California, Mexico, recorded by remote sensing. Geophysical Research Letters. 2016; 43(13):7066-71.

45. Kasie TA, Demissie BS, Bahry MJ, Gessesse GM, Wale LE. The impact of the 2015 El Niño-induced drought on household consumption: Evidence from Rural Ethiopia. Climate and Development. 2019;1-0.

46. Wolde-Georgis T. El Nino and drought early warning in Ethiopia. Internet Journal of African Studies. 1997;1(2).

47. Korecha D, Sorteberg A. Validation of operational seasonal rainfall forecast in Ethiopia. Water Resources Research. 2013;49(11):7681-97.

48. IRIDL. Forecast for Jul-Sep 2015, Forecast Issued May 2015. New York: International Research Institute for Climate and Society; 2015b.

Available:http://iridl.Ideo.columbia.edu/map room/IFRC/FIC/prcp_fcst.html?bbox=bb\%3 A26.21\%3A-

$28.80 \% 3 \mathrm{~A} 65.10 \% 3 \mathrm{~A} 17.22 \% 3 \mathrm{Abb} \& \mathrm{~F}=$ May $\% 202015 \& \mathrm{~L}=2.0$

49. IRIDL. Forecast for Jun-Aug 2015, Forecast Issued May 2015. New York: International Research Institute for Climate and Society; 2015a.

Available:http://iridl.Ideo.columbia.edu/map room/IFRC/FIC/prcp_fcst.html?bbox=bb\%3 A26.21\%3A-

$28.80 \% 3 \mathrm{~A} 65.10 \% 3 \mathrm{~A} 17.22 \% 3 \mathrm{Abb} \& \mathrm{~F}=$ May \%20 2015\&L=1.0

50. Cervigni R, Morris M, Eds. Confronting drought in Africa's drylands: Opportunities for enhancing resilience. Washington, DC: World Bank. 2016.

51. WB (World Bank). World Bank. A Country Study on the Economic Impacts of Climate Change, Environment and Natural Resource Management, Sustainable Development Department, Africa Region, Development Prospects Group. Report No. 46946-ET; 2008.

52. Degefu W. Some aspects of meteorological drought in Ethiopia. 
Cambridge: Cambridge University Press; 1987.

53. Abrha MG, Simhadri S. Effects of rainfall variability on production of five major cereal crops in Southern Tigray, Northern Ethiopia. Octa Journal of Environmental Research. 2015;3(1).

54. AKLDP. EI Niño in Ethiopia Early impacts of drought in Amhara National Regional State; 2016.

55. AKLDP. El Niño and Indebtedness in Ethiopia: Impacts of drought on household debts in Tigray National Regional State. London: AKLDP; 2016b.

Available:www.agri-learningethiopia.org/wpcontent/uploads/2016/01/A KLDP-Indebtedness-study.pdf

56. Fiona M, Eden M. Drought, resilience and self help in Ethiopia: A review of TearFund Self Help Groups following El Niño. Agriculture Knowledge, Learning, Documentation and Policy Project (AKLDP-Ethiopia); 2016.

57. Hassen A, Zewdu T, Tolera A, Korecha D. Interconnection between El-Niño-Southern oscillation induced rainfall variability, livestock population dynamics and pastoralists adaptation strategies in Eastern Ethiopia. In Proceedings of the International Conference on Impact of El Niño on Biodiversity, Agriculture and Food Security, 23-24 February,
Harayama University, Ethiopia; 2017.

58. Weldegebriel ZB. Social protection and vulnerability to climate shocks: A panel data evidence from Rural Ethiopia. Ethiopian Journal of the Social Sciences and Humanities. 2016;12(2):99-132.

59. Kidane G, Alemneh D, Meshack M. Agricultural based livelihood systems in drylands in the context of climate change: Inventory of adaptation practices and technologies of Ethiopia. Final Draft; 2009.

60. Burnett D. Stage 2-supporting climate resilient value chains. Final Report: Stage 2-supporting climate resilient value chains; 2013.

61. WFP/World Food Program. Climate risk and food security in Ethiopia: Analysis of climate impacts on food security and livelihoods; 2014.

62. Ali $H$. Pastoralists and agro-pastoralists vulnerability to climate change and adaptation response: The case of Aysaita Woreda, Afar Regional State, Northern Ethiopia. Doctoral Dissertation, Addis Ababa University. 2017;

63. Regassa S, Givey C, Castillo G. The rain doesn't come on time anymore: Poverty, vulnerability and climate variability in Ethiopia. Oxfam Policy and Practice: Climate Change and Resilience. 2010;6(1): 90-134.

(C) 2020 Gitima and Mersha; This is an Open Access article distributed under the terms of the Creative Commons Attribution License (http://creativecommons.org/licenses/by/4.0), which permits unrestricted use, distribution, and reproduction in any medium, provided the original work is properly cited. http://www.sdiarticle4.com/review-history/55608 